\title{
INWENTARZ PARAFII RACLAWICE Z 1923 ROKU
}

\begin{abstract}
Streszczenie
Parafia Racławice k. Niska, została erygowana na przełomie XIII/XIV wieku. Źródła historyczne poświadczają w okresie staropolskim obecność co najmniej 3 kościołów. W połowie XVIII wieku właściciel części Racławic i Przędzela, Józef Grabiński, ufundował świątynię, która spłonęła w 1914 roku. Po odzyskaniu niepodległości przez Polskę w 1918 roku przystąpiono do budowy nowego ośrodka kultu. Świątynia została poświęcona 8 maja 1922 roku. Inwentarz parafialny z 1923 roku ukazuje wysiłek, jaki duchowieństwo i wierni podjęli, by wyposażyć kościół w niezbędne paramenty liturgiczne.

Słowa kluczowe: Racławice; inwentarze kościołów parafialnych; historia Kościoła
\end{abstract}

Parafia pw. św. Stanisława Biskupa i Męczennika w Racławicach, znajdująca się obecnie w granicach diecezji sandomierskiej, została erygowana między 1253 (kanonizacja patrona w Asyżu) a 1326 rokiem (pierwsza wzmianka źródłowa) ${ }^{1}$. Do 1772 roku przynależała do diecezji krakowskiej, archidiakonatu sandomierskiego, dekanatu rudnickiego. Na przełomie XVIII/XIX wieku zaszły zmiany w organizacji terytorialnej Kościoła na ziemiach polskich. W 1772 roku, wskutek I zaboru, Racławice znalazły się na terytorium Austrii². Weszły w skład obszaru diecezji krakowskiej, położonego między Wisłą, Sanem i Karpatami, który został oderwany od swojej stolicy w Krakowie. Przyjął on nazwę diecezji zawiślańskiej (Civistulana dioecesis Cracoviensis) i obejmował 26 dekanatów, 400

* Ks. Tomasz Moskal - dr hab. historii Kościoła, prof. KUL; Instytut Historii Kościoła i Patrologii KUL; e-mail: tomasz.moskal@kul.pl

https://orcid.org/0000-0002-0174-893X

${ }^{1}$ J. Rawski, Wybrane zagadnienia dotyczace administracji kościelnej $w$ widłach Wisty i Sanu, Tarnobrzeg 1997, s. 31; W. Kowalski, Uposażenie parafii archidiakonatu sandomierskiego w XV-XVIII wieku, Kielce 1998, s. 353-354.

${ }^{2}$ B. Kumor, Dzieje diecezji krakowskiej do r. 1795, t. 4, Kraków 2002, s. 212. 
parafii i 1139436 wiernych $^{3}$. Po erygowaniu w 1786 roku diecezji tarnowskiej, parafia racławicka znalazła się w jej granicach, które zostały jednakże w tymże roku skorygowane i 3 dekanaty: głogowski, rudnicki i miechociński przyłączono do diecezji przemyskiej ${ }^{4}$. Obszar parafialny stanowiły wówczas wioski: Racławice, Wolina, Nowa Wieś, Przędzel, Stróża, Nisko, Zarzecze, Huta Deręgowska. W XIX wieku dołączyły Kończyce, część Nowosielca i Podwolina. Curkumskrypcja z 1992 roku przyłączyła Racławice do diecezji sandomierskiej ${ }^{5}$.

Kościół parafialny służący wiernym w XIX wieku został ufundowany przez Józefa Grabińskiego (1710-?), podczaszego wieluńskiego, który po 1730 roku nabył część Racławic i Przędzela. Świątynię konsekrował 26 października 1742 roku sufragan krakowski Michał Kunicki (1698-1751)6. Wybudowano ją z modrzewia. Wnętrze zostało bogato ozdobione dzięki hojnym darczyńcom. Dość wspomnieć, że obraz patrona parafii, św. Stanisława, umieszczony w głównym ołtarzu, posiadał srebrną infułę i posrebrzaną miedzianą sukienkę. Ufundował je Stanisław Lochmanowicz, ówczesny administrator w Przędzelu? ${ }^{7}$ Podczas wizytacji w 1765 roku stwierdzono ponadto srebrny, wyzłocony krzyż i łańcuszek na piersi świętego oraz srebrny pastorał ${ }^{8}$. Z kolei podczaszy stężycki, Stefan Bukowski, ufundował sukienkę srebrną oraz takież same promienie wokół głowy na obrazie św. Antoniego. Postacie Jezusa i Matki Najświętszej na tym obrazie posiadały srebrne koronki. Także wyobrażenie św. Kajetana ozdobiono promieniami na głowie, postacie zaś Jezusa i Maryi miały srebrne korony, które ufundowała Konstancja Mniszkowa, cześnikowa podolska9 .

Troska miejscowego duchowieństwa oraz ofiarność parafian pozwoliły utrzymać świątynię i jej wyposażenie przez całe XIX stulecie. Na początku XX wieku biskup sufragan przemyski Józef Fischer (1847-1931) stwierdził w protokole powizytacyjnym: „W Racławicach jest kościół drewniany, który stoi przeszło 150

${ }^{3}$ B. Kumor, Granice metropolii i diecezji polskich (966-1939), „Archiwa Biblioteki i Muzea Kościelne", 19 (1969) s. 286-287.

${ }^{4}$ B. Kumor, Ustrój i organizacja Kościoła polskiego w okresie niewoli narodowej 1772-1918, Kraków 1980, s. 161.

${ }^{5}$ Rocznik Diecezji Sandomierskiej 1994, red. Z. Kończak, Sandomierz 1994, s. 226-227.

${ }^{6}$ J. Kracik, Konsekracje kościołów i ołtarzy $w$ diecezji krakowskiej w XVII-XVIII w., „Nasza Przeszłość", 61 (1984) s. 140.

${ }^{7}$ Archiwum Kurii Metropolitalnej w Krakowie (dalej: AKMK), sygn. AV-42, Acta visitationis in decanatibus Rudnicensi et Miechocinensi sub auspiciis et regimine Cel. R.D. Andreae Stanislai Kostka comitis in Zatuskie Zatuski, episcopi Cracoviensis, ducis Severiae, per me Andream Potocki canonicum ecclesiarum cathedralium Chelmensem et coadiutorem Cracoviensem archidiaconum et officialem Sandomieriensem, expeditae diebus Januarii, Februarii et Martii a. D. 1748, s. 75.

${ }^{8}$ AKMK, sygn. A-51, Acta visitationis ecclesiarum in archidiaconatu Sandomieriensi consistentium de speciali mandato Cel. Principis R.D. Cajetani Ignatii Soltyk, episcopi Cracoviensis, ducis Severiae, per me Joannem Cantium Ligęza STD, ecclesiarum Insignis Collegiatae Sandomieriensis archidiaconum in Trójca curatum expeditae a.D. 1764 inchoatae annisque sequentibus 1765 et 1766 terminatae. (Decanatus: Połanecensis, Miechocinensis, Rudnicensis et Coprivnicensis), s. 74 .

${ }^{9}$ AKMK, sygn. AV-42, Acta visitationis, s. 75. 
lat, ale jest dobrze utrzymany. Posiada kilka starożytnych pięknych ornatów"10. Niestety, już w protokole następnej wizytacji biskup ordynariusz Józef Sebastian Pelczar (1842-1924) zauważył:

Ubogi drewniany kościólek, wystawiony w roku 1746, a konsekrowany w 1748 przez Michała Kunickiego, biskupa sufragana krakowskiego, wewnątrz wymalowany i w porządku utrzymywany, chyli się ku upadkowi i długo już stać nie może $\mathrm{e}^{11}$.

Proboszcz racławicki, ks. Wojciech Sapecki (1844-1922), który objął parafię po ks. Józefie Günterze (1832-1905), nosił się z zamiarem budowy nowej świątyni. Niestety, wybuchła I wojna światowa. W kronice miejscowej szkoły znajduje się opis wydarzeń z 1914 roku:

W pierwszych dniach sierpnia wypowiedziała wojnę Austria Rosji [...] We wrześniu 1914 wojska nasze, zaczęły opuszczać stanowiska w Rosji a cofać się w głąb Galicji. Po obu brzegach Sanu przyszło do krwawych, strasznych walk z Rosjanami. Wojska austriackie zajęły obronne stanowisko na polach Racławickich i w samej wiosce. Bój trwał przez 6 tygodni dzień i noc. Mieszkańcy wsi wśród huku dział, kul karabinowych i maszynowych uchodzili nocą w miejsca bezpieczniejsze. Wioskę całą, kościół, nieprzyjaciel spalił12.

W „Kronice Diecezji Przemyskiej” zaś odnotowano:

Racławice, kościół paraf[ialny] drewniany z r. 1746 - spłonął doszczętnie z całym wyposażeniem i przyborami liturgicznymi. Nabożeństwo wśród murów plebanii częściowo tylko ocalałych ${ }^{13}$.

Po odzyskaniu niepodległości przez Polskę w 1918 roku rozpoczęto budowę nowego kościoła. Ks. Sapecki z parafianami podjął się ogromnego trudu, uwieńczonego poświęceniem tymczasowej świątyni w uroczystość odpustową 8 maja 1922 roku. Jednakże jej wyposażanie było wówczas bardzo skromne. Zachowane protokoły zdawczo-odbiorcze oraz inwentarze parafialne z tego okresu pozwalają m.in. odtworzyć mozolny i kosztowny proces wyposażania kościoła w pierwszych latach budowy ${ }^{14}$. Ich publikacja ukazuje zaangażowanie i wkład duchownych oraz

${ }^{10}$ Wizytacja kanoniczna dekanatu rudnickiego, dokonana przez ks. bpa sufragana Karola Józefa Fischera r. 1901, „Kronika Diecezji Przemyskiej”, 2 (1902) s. 368.

${ }^{11}$ Wizytacja kanoniczna dekanatu rudnickiego, dokonana przez ks. bpa Józefa Sebastiana Pelczara wr. 1911, „Kronika Diecezji Przemyskiej”, 12 (1912) s. 516-517.

${ }^{12}$ Archiwum Szkoły w Racławicach, Kronika szkoły powszechnej w Racławicach, s. 2.

${ }^{13}$ Wykaz kościołów diecezji przemyskiej ob. łać. wskutek wojny całkowicie zniszczonych lub czesściowo uszkodzonych, „Kronika Diecezji Przemyskiej”, 17 (1917) s. 49.

${ }^{14}$ Wśród opublikowanych w ostatnim czasie tego rodzaju tekstów można wskazać: M. Janakowski, Inwentarz kościoła parafialnego w Chlewiskach z lat 1865-1866, „Z Dziejów Regionu i Miasta: rocznik Polskiego Towarzystwa Historycznego w Skarżysku-Kamiennej”, 6 (2015) s. 119-151; P. Szkutnik, Opis kościoła i probostwa w Szadku w połowie XIX w., „Biuletyn Szadkowski”, 15 (2015) s. 69-87; M. Karkocha, Opis probostwa w Matogoszczu z 1856 roku, „Przegląd Nauk Historycznych", 17 (2018) nr 1, s. 143-170; W. Żurek, Inwentarz rzymskokatolickiego kościoła parafialnego w Kobryniu z 21 sierpnia 1933 roku, „Archiwa Biblioteki i Muzea Kościelne”, 109 (2018) s. 399-412; tenże, Inwentarz rzymskokatolickiego kościoła parafialnego w Siehniewiczach z 14 maja 1930 roku, „Archiwa Biblioteki i Muzea Kościelne”, 110 (2018) s. 465-476; tenże, Parafialny 
parafian w jego uświetnienie, jak i koszty przez nich wówczas poniesione. Zachętą do ich publikacji są również cenne uwagi archiwistów i historyków, podkreślające wartość tego rodzaju źródeł, których w archiwum parafialnym dla okresu 1923-1954 jest przechowywanych 6 z różnych lat ${ }^{15}$.

\section{Podstawa wydania}

Publikowanym dokumentem jest „Protokół spisany na rzym. kat. probostwie w Racławicach dnia 10 marca 1923 wskutek rozporządzenia Starostwa z dnia 2/3 1923 L:3129/2 z powodu zabezpieczenia administrowanego przez Ks. Stanisława Lubasa majątku kościelnego i beneficjalnego po śp. plebanie Wojciechu Sapeckim i oddania tegoż majątku nowo instytuowanemu proboszczowi Ks. Gerardowi Kielarowi". Został on sporządzony 10 marca 1923 roku. Jest to maszynopis liczący 9 nienumerowanych luźnych kart o wymiarach $217 \mathrm{~mm} \times 270 \mathrm{~mm}$. Wyżej wspomniano, że jest on przechowywany w archiwum parafialnym w Racławicach. Niemniej jednak, jak można wywnioskować z załączonego doń pisma, pierwotnie znajdował się w zasobie Kurii Diecezjalnej w Przemyślu. W liście biskupa J. Fischera adresowanym do dziekana rozwadowskiego ks. Michała Dukieta (1864-1933) czytamy:

Przesyłamy w załączeniu protokół zabezpieczenia majątku kościelnego spisany w dniu 10 marca 1923 przez delegata Starostwa w Nisku i polecamy wykorzystać tenże protokół przy oddawaniu mienia kościelnego w opiekę i zarząd obecnemu duszpasterzowi w Racławicach, a następnie przesłać go do Naszej Kurii wraz z odpisem protokołu tegorocznego zabezpieczenia ${ }^{16}$.

Absencja tego dokumentu w Archiwum Archidiecezji Przemyskiej pozwala wysnuć wniosek, że protokołu nie odesłano. O jego użyteczności może świadczyć fakt dopisków ręcznych, sporządzonych zapewne w 1930 roku. Przy jego opracowaniu dziekan korzystał prawdopodobnie z przygotowanego formularza. Swiadczyć o tym mogą braki i opuszczenia pod niektórymi elementami opisu.

Trzeba też wspomnieć, że uzupełnieniem do wydawanego protokołu jest sporządzony 12 marca 1923 r. „Wykaz ubytków i przybytków w majątku kościelnym i beneficjalnym probostwa w Racławicach". Maszynopis liczący 5 kart nienumerowanych formatu $210 \mathrm{~mm} \times 280 \mathrm{~mm}$ został sporządzony w starostwie niżańskim.

kościót farny świętych Joachima i Anny we Włodzimierzu Wołyńskim w 1831 roku, „Archiwa Biblioteki i Muzea Kościelne”, 111 (2019) s. 423-433.

${ }^{15}$ Zob. m.in. R.R. Kufel, Kancelaria, registratura i archiwum parafialne na ziemiach polskich od XII do początku XXI wieku, Zielona Góra 2011, s. 59, 84; E. Markowska, Archiwum parafialne i jego zasób na przykładzie archiwum rzymskokatolickiej parafii pod wezwaniem Świętej Anny w Białej Podlaskiej, „Radzyński Rocznik Humanistyczny”, 7 (2009) s. 24-25.

${ }^{16}$ List z protokołem zostały wysłane z racji przejęcia parafii Racławice przez ks. Franciszka Zmarzłego (1889-1956) od tymczasowego administratora ks. Tadeusza Wieloboba (1906-1971). Warto zwrócić uwagę, że został on wysłany już po sporządzeniu protokołu z tej okazji, co miało miejsce 11 sierpnia 1930 roku (Archiwum Parafii Racławice, dalej: APR), Przemyśl, 16 sierpnia 1930, List Kurii Biskupiej do Dziekana w Rozwadowie; tamże, Protokót spisany na probostwie rzym. kat. w Ractawicach dnia 11 sierpnia 1930 r. z powodu oddania majątku kościelnego i plebańskiego nowemu proboszczowi ks. Franciszkowi Zmarzłemu przez administratora ks. Tadeusza Wieloboba). 
Przyjęto układ dwukolumnowy, gdzie w pierwszej wykazano ubytki, w drugiej zaś przybytki. Powtarza on treść edytowanego dokumentu.

\section{PROTOKÓ£}

spisany na rzym[sko] kat[olickim] probostwie w Racławicach dnia 10 marca 1923 wskutek rozporządzenia Starostwa z dnia 2/3 1923 L:3129/2 z powodu zabezpieczenia administrowanego przez Ks. Stanisława Lubasa ${ }^{17}$ majątku kościelnego i beneficjalnego po śp. plebanie Wojciechu Sapeckim ${ }^{18}$ i oddania tegoż majątku nowo instytuowanemu proboszczowi Ks. Gerardowi Kielarowi ${ }^{19}$.

${ }^{17}$ Ks. Stanisław Lubas (1890-1970). Pochodził z Majdanu Królewskiego. W latach 1904-1912 uczęszczał do gimnazjum w Rzeszowie, po czym wstąpił do Wyższego Seminarium Duchownego w Przemyślu. Święcenia kapłańskie przyjął w katedrze przemyskiej 6 maja 1917 roku z rąk biskupa przemyskiego Józefa Sebastiana Pelczara (1842-1924), kanonizowanego w 2003 roku. Jako wikariusz pracował w parafiach Boguchwała, Lesko, Korczyna. Dnia 1 lipca 1922 roku otrzymał nominację na wikariat w Racławicach. Po śmierci proboszcza racławickiego, ks. Wojciecha Sapeckiego, który zmarł 29 grudnia 1922 roku, pełnił do 27 lipca 1923 roku urząd administratora. Później został przeniesiony na wikariat w Pysznicy, a następnie w Błażowej. W 1927 roku został proboszczem w Żyznowie, a w 1934 roku do śmierci w Przewrotnem. Odznaczony „Expositorio Canonicale” w 1935 roku oraz przywilejem noszenia rokiety i mantoletu w 1953 roku (Archiwum Archidiecezji Przemyskiej (dalej: AAP), Akta personalne księży (dalej: Apk), Tabela służbowa (dalej: Ts.), lit. „L”, Tabela stużbowa ks. Stanisława Lubasa; T. Moskal, Duszpasterze parafii Ractawice w latach 1918-1939, „Archiwa Biblioteki i Muzea Kościelne”, 92 (2009), s. 172.

${ }^{18}$ Ks. Wojciech Sapecki (1844-1922). Pochodził z Rymanowa. Uczył się gimnazjum w Przemyślu, które ukończył w 1867 roku, po czym rozpoczął studia prawnicze na Uniwersytecie Jana Kazimierza we Lwowie, które przerwał po dwóch latach, wstępując do Wyższego Seminarium Duchownego w Przemyślu. Święcenia kapłańskie przyjął 15 czerwca 1873 roku z rąk biskupa przemyskiego Macieja Hirschlera (1807-1881). Jako wikariusz pracował w parafiach: Jeżowe, Rozwadów, Ślęzaki. W 1879 roku otrzymał probostwo w Radomyślu nad Sanem. Od 19 stycznia 1907 roku do śmierci 22 grudnia 1922 roku był proboszczem w Racławicach. W 1905 roku otrzymał przywilej „Expositorio Canonicale” (AAP, Apk, Ts., lit. „S”, Tabela stużbowa ks. Wojciecha Sapeckiego; Moskal, Duszpasterze parafii Ractawice, s. 166-168; M. Kowalik, Ł. Szczurowski, Wojciech Sapecki, w: Przeszli przez tę ziemię czyniąc dobro. Cmentarz w Racławicach, red. B. Barć, Stalowa Wola 2012, s. 53).

19 Ks. Gerad Kielar (1879-1939). Pochodził z Haczowa. Od 1892 roku uczył się w gimnazjum w Haczowie. Po jego ukończeniu wstąpił w 1900 roku do Wyższego Seminarium Duchownego w Przemyślu, które ukończył przyjęciem 24 czerwca 1904 roku święceń kapłańskich z rąk biskupa Józefa Sebastiana Pelczara. Jako wikariusz pracował w parafiach: Tuligłowy, Sambor, Przybyszówka, Jarosław, jako zaś wikariusz exponowany w Samborze (1910-1911), Nisku (19121923). Od 7 marca 1923 roku do 19 maja 1930 roku proboszczował w Racławicach. Po ich opuszczeniu pracował do śmierci w Brzozowie, pełniąc oprócz urzędu rządcy parafii, także funkcję dziekana brzozowskiego (od 1934 roku). W 1935 roku otrzymał przywilej noszenia rokiety i mantoletu (AAP, Apk, Ts., lit. „K”, Tabela stużbowa ks. Gerarda Kielara; Moskal, Duszpasterze parafii Racławice, s. 169-170). 
Obecni.

Józef Kornecki ${ }^{20}$ jako Przewodniczący Komisji

Ks. Michał Dukiet ${ }^{21}$ Dziekan w Rozwadowie jako Delegat Ordynariatu biskupiego w Przemyślu legitymowany dekretem tegoż Ordynariatu z dnia 3/3 1923 L:116(1)/23

Ks. Gerard Kielar nowo insytytuowany proboszcz

Ks. Stanisław Lubas administrator parafii

Jerzy Pieróg ${ }^{22}$ przewodniczący miejscowego komitetu kościelnego

Wojciech Młynarski ${ }^{23}$ członek miejscowego komitetu kościelnego

Franciszek Siek ${ }^{24}$ członek miejscowego komitetu kościelnego

Franciszek Karaś ${ }^{25}$ członek miejscowego komitetu kościelnego

Wojciech Dąbek ${ }^{26}$ zaprzysiężony taksator gminy ponadto obecny

Antoni Łasica generalny pełnomocnik spadkobierców po śp. Ks. Wojciechu Sapeckim, który przedstawił pełnomocnictwo notarialne z daty Bystrzyca Dolna 12/2 1923 wystawione przez Ignacego Sapeckiego ${ }^{27}$ a uwierzytelniony odpis tegoż pełnomocnictwa załącza się.

W przytomności powyższych osób przystąpił Przewodniczący komisji do szczegółowych oględzin części składowych majątku kościelnego a następnie beneficjalnego porządkiem inwentarza parafialnego i do oddania tegoż majątku w zarząd i użytkowania nowo ustanowionemu proboszczowi ks. Gerardowi Kielarowi.

${ }^{20}$ Józef Kornacki, delegat Starostwa w Nisku, urzędnik VII stopnia służbowego (APR, Dokumenty luźne, Przemyśl, 16 sierpnia 1930, List Kurii Biskupiej do Dziekana w Rozwadowie).

${ }^{21}$ Ks. Michał Dukiet (1864-1933). Pochodził z Dubiecka. Uczył się w gimnazjach w Rzeszowie i Przemyślu, po czym wstąpił do Wyższego Seminarium Duchownego w Przemyślu. Święcenia kapłańskie przyjął 20 lipca 1890 roku z rąk biskupa Łukasza Soleckiego (1827-1900). Jako wikariusz pracował w parafiach: Jasło, Gorlice, Gorzyce. W 1901 roku otrzymał probostwo w Rozwadowie. Od 1911 roku pełnił obowiązki dziekana rudnickiego, a po podziale dekanatów w 1931 roku dziekana rozwadowskiego (S. Momidłowski, Wspomnienia pośmiertne o przemyskich kapłanach, Przemyśl 2019, s. 49-52).

${ }^{22}$ Jerzy Pieróg, parafianin z Racławic, członek Komitetu Kościelnego, obecny również przy spisywaniu późniejszych inwentarzy kościelnych: 3 czerwca i 11 sierpnia 1930 roku.

${ }^{23}$ Wojciech Młynarski, parafianin z Racławic, członek Komitetu Kościelnego, obecny również przy spisywaniu późniejszych inwentarzy kościelnych: 3 czerwca i 11 sierpnia 1930 roku.

${ }^{24}$ Franciszek Siek, parafianin z Racławic, członek Komitetu Kościelnego.

${ }^{25}$ Franciszek Karaś, parafianin z Racławic, członek Komitetu Kościelnego.

${ }^{26}$ Wojciech Dąbek, zaprzysiężony taksator gminy, obecny również przy spisywaniu późniejszych inwentarzy kościelnych: 3 czerwca i 11 sierpnia 1930 roku.

${ }^{27}$ Ignacy Sapecki, brat ks. Wojciecha Sapeckiego oraz ks. Pawła Sapeckiego (1837-1930), wieloletniego proboszcza w Sędziszowie Małopolskim (Momidłowski, Wspomnienia pośmiertne, s. 275-281). 
[s. 2]

\section{A. INWENTARZ KOŚCIELNY \\ I. Opis kościoła i jego urządzeń.}

A. Kościół i zakrystia

Kościół wraz z całym wewnętrznym urządzeniem spalił się w roku 1914 wskutek wypadków wojennych.

$\mathrm{Na}$ jego miejsce postawiono prowizoryczny kościół z desek na dawnym fundamencie z krzyżaków obitych deskami z zewnątrz i wewnątrz o szesnastu oknach $\mathrm{z}$ zakrystią $\mathrm{z}$ jednej strony i skarbcem $\mathrm{z}$ drugiej strony.

\section{B. Dzwonnica}

W miejsce dawnej dzwonnicy drewnianej wybudowano w roku 1911 dzwonnicę murowaną piętrową nakrytą dachem blaszanym zniszczonym wskutek wypadków wojennych.

\section{Ołtarze}

\section{3,4,5 nie ma.}

Dawne ołtarze spaliły się w roku 1914 wraz z kościołem, w ich miejsce wstawiono do nowego kościoła jeden wielki ołtarz i dwa boczne zrobione z desek do tymczasowego użytku.

\section{Konfesjonały 6.7.8.}

Nie ma.

Dawne konfesjonały zostały spalone razem z kościołem w roku 1914. Obecnie zastano w nowym kościele trzy nowe konfesjonały a to: jeden z pręci a dwa $z$ desek. ${ }^{(4)}+2^{\text {(dopisek ręczny powyżej) }}$

\section{E. Kazalnica}

Nie ma.

Obecnie znajduje się w nowym kościele kazalnica prowizoryczna z desek ze schodkami.

[s. 3].

$$
\text { F. Organy }
$$

Nie ma, gdyż spaliły się w roku 1914. Zastano fisharmonię (dopisek ręczny powyżej) nożną dwugłosową z pedałem ${ }^{28}$.

\section{G. Dzwony}

Zastano tylko jeden dzwon gdyż dwa inne zostały zajęte przez władze austriac$k_{i e}{ }^{29}$. Należytość pobrał śp. Ks. Wojciech Sapecki. Ani Komitetowi kościelnemu

${ }^{28}$ Została zakupiona w Krakowie za 170000 marek (dalej: mk) (APR, Księga dochodów i rozchodów kasy kościelnej w parafii Ractawice z lat 1919-1950, 1921 r.)

${ }^{29}$ Dzwon został odlany w 1663 roku, ważył $110 \mathrm{~kg}$ i miał średnicę $58 \mathrm{~cm}$, wysokość $45 \mathrm{~cm}$. Został zarekwirowany przez Niemców 25 października 1941 roku. Urząd parafialny otrzymał sto- 
ani Ks. administratorowi nie jest wiadomym jaka kwota została przez percypienta pobrana, gdzie i jak została ona ulokowana. Wszystkie inne dzwonki wraz z sygnaturką spaliły się w roku 1914.

Znaleziono nową sygnaturkę ${ }^{30}$, następnie jeden harmonijny przy zakrystii, dwa harmonijne ołtarzowe i dwa pojedyncze dzwonk $\mathrm{i}^{31}$.

\section{H. Ch[rz]cielnica}

Nie ma, spalona w roku 1914, nowej również nie ma.

$$
\text { I, K, L }
$$

\section{Miedź i mosiądz}

Zastano starą monstrancję, trzy kielichy miedziane, z których jeden ozłocony z zewnątrz i wewnątrz, drugi złocony wewnątrz a zewnątrz posrebrzany, a trzeci stary nie do użytku nie posrebrzony ani nie ozłocony, oraz lampkę wieczną przed wielkim ołtarzem z brązu.

Ponadto zastano jedną puszkę $\mathrm{w}$ tabernakulum miedzianą całą pozłacaną + puszka srebrna pozłacana (dopisek ręczny powyżej), następnie dwa naczyńka dla chorych + jedno (dopisek ręczny poniżej) z miedzi pozłacane. Innych przedmiotów inwentarzu pod M. wymienionych nie ma, gdyż zostały w roku 1914 spalone.

\section{N. Cyna i ołów.}

Nie ma, natomiast zastano naczyńko do chrztu +1 nowe (dopisek ręczny powyżej) z ołowiu, cztery tacki cynowe, kropielnica cynowa, dwanaście lichtarzy cynowych, 6 małych lichtarzy cynowych i naczynie do umywania rąk cynowe + 6 dużych (dopisek ręczny poniżej).

[s. 4]
O. Żelazo

Nie ma, zastano jeden krzyż procesyjny ${ }^{32} \mathrm{i}$ kropielnicę w przedsionku do użytku parafian.

\section{P. Drzewo}

Nie ma, spalone w roku 1914 razem z kościołem.

\footnotetext{
sowne zaświadczenie 27 lutego 1942 roku. Zarekwirowano także dzwon znajdujący się na cmentarzu, ważący 23 kg, o średnicy 36 cm i wysokość 31 cm z 1920 roku (APR, Dokumenty luźne; AAP, Teczka z ankietami z 1945 r. o stanie parafii w czasie II wojny światowej, Teczka „K - Z”, Dekanat rudnicki, Ankieta parafii Racławice - błędnie podany 1943 rok).

${ }^{30}$ Wykonana w 1920 roku o wadze 15 kg. Zabrana przez Niemców w 1943 roku. Tamże.

${ }^{31} \mathrm{Na}$ dzwonki ofiarę złożyli m.in. Anna i Jan Samek - 500 mk. W 1921 roku zakupiono dzwonki za 450 mk, dzwonki do zakrystii za 3900 mk, dzwonki do Mszy Świętej za 850 mk (APR, Księga dochodów i rozchodów, 1921 r.).

${ }^{32}$ Krzyż wielki procesyjny został zakupiony za 7000 mk w 1921 roku (APR, Księga dochodów i rozchodów, $1921 \mathrm{r}$.).
} 
Znaleziono dwanaście lichtarzy z drzewa do katafalku ${ }^{33}$ i sześć lichtarzy ołtarzowych $^{34}$, katafalk o trzech stopniach, trzy stopnie ołtarzowe, jedenaście ławek ${ }^{35}$, jeden krzyż procesyjny ${ }^{36}$, kredens drewniany37, dwa krzesła gięte stare, klęcznik w zakrystii i kazalnica na cmentarzu kościelnym.

\section{Szaty liturgiczne}

\section{Białej barwy}

Nie ma. Zastano natomiast cztery białe ornaty z których dwa są nowe a dwa częściowo zużyte, wszystkie ze zwykłej materii bez ornamentyki +biały wolumnie św. Franciszek (dopisek ręczny poniżej).

\section{[2.] Czerwonej barwy}

Trzy ornaty ze zwykłej materii bez ornamentyki z których jeden jest w dobrym stanie a dwa częściowo zużyte.

\section{[3.] Zielonej barwy}

Dwa ornaty zwykłe bez ozdób w dobrym stanie.

[4.] Fioletowej barwy.

Dwa ornaty zwykłe bez ozdób z których jeden jest dobrym stanie, drugi częściowo zużyty.

\section{[5.] Czarnej barwy}

Jeden ornat w dobrym stanie ${ }^{+ \text {nowy (dopisek ręczny poniżej). }}$

\section{R. Kapy}

Nie ma. Wszystkie spaliły się w r. 1914. Zastano natomiast 2 (dopisek ręczny powyżej) duże białe kapy zwykłe bez ozdób, jedna z nich jest w dobrym stanie, druga w gorszym przybyła czarna kapa (dopisek ręczny ponizzj).

\section{[s. 5]}

\section{S. Bielizna kościelna}

Nie ma. Spalona w r. 1914. Zastano natomiast 6 obrusów ołtarzowych spodnich i sied[e]m ${ }^{13}$ (dopisek ręczny powyżej) obrusów ołtarzowych wierzchnich, pięć ${ }^{4 \text { (do- }}$ 1921 r.).

${ }^{33}$ Lichtarze zostały zakupione za $4000 \mathrm{mk}$ w 1921 roku (APR, Księga dochodów i rozchodów,

${ }^{34} 6$ lichtarzy oraz 1 chorągiew zakupiono za $33450 \mathrm{mk}$ w 1921 roku (APR, Księga dochodów i rozchodów, $1921 \mathrm{r}$.).

${ }^{35} 10$ ławek kosztowało w 1921 roku 15000 mk (APR, Księga dochodów i rozchodów, 1921 r.).

${ }^{36}$ Krzyż procesyjny kosztował w 1921 roku 2000 mk (APR, Księga dochodów i rozchodów, 1921 r.).

${ }^{37}$ Komoda drewniana kosztowała w 1921 roku 8335 mk (APR, Ksiega dochodów i rozchodów, 1921 r.). 
pisek ręczny powyżej) $\mathrm{alb}, \operatorname{sied}[\mathrm{e}] \mathrm{m}^{3}{ }^{3 \text { (dopisek rẹczny powyżej) }}$ komży księżych, dwie ${ }^{+2 \text { (dopisek ręzny }}$ powyżj) komże dla ministrantów, cztery paski, sześć małych obrusków na tabernaculum, dwanaście korporałów, piętnaście palek, dwadzieścia 25 (dopisek ręczny powyżej) cztery puryfikaterzy, czternaście humerałów i sied[e]m ${ }^{15 \text { (dopisek ręczny powyżej) }}$ ręczników do laraba [sic!].

\section{T. Inne przedmioty}

Nie ma, gdyż spalone w r. 1914. Zastano natomiast jedno imraculum[sic!], os[ie]m ${ }^{9 \text { (dopisek ręczny powyżej) }}$ stuł różnego koloru, duże tuwalnie: jedna nowa ${ }^{38}$, druga

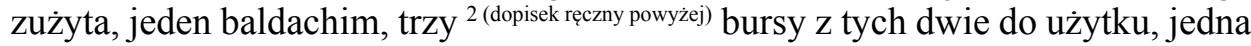
zupełnie zniszczona, cztery ${ }^{5 \text { (dopisek ręczny powyzej) }}$ poduszki pod mszały, dwie ${ }^{+2 \text { nowe }}$ (dopisek ręczny powyżej) białe chorągwie $\mathrm{i}^{+2}$ czarne(dopisek ręczny powyżej), dziesięć lamp naftowych zwyczajnych wiszących, sześć kanonów ${ }^{+3}$ nowe (dopisek ręczny powyżej) eperatio ad missam, cztery pary ampulek szklanych i figura Chrystusa w grobie ${ }^{39}$.

\section{U. Obrazy}

Nie ma. Spalone w r. 1914. Znaleziono nowe czternaście obrazów „Drogi Krzyżowej”"40, obraz pana Jezusa w Ogrojcu w wielkim ołtarzu ${ }^{41}$, na płótnie olejną farbą malowany, dwie statuy Matki Boskiej ${ }^{42}$ i Serca Pana Jezusa i figurka Chrystusa Zmartwychwstałego ${ }^{43}$.

\section{W. Księgi kościelne}

Nie ma, spalone w r. 1914.

Zastano natomiast trzy mszały zużyte $\mathrm{z}$ tych dwa duże, jeden żałobny, trzy rytuały małe + graduat nowy (dopisek ręczny powyżej) $i$ jedną ewangelię na niedzielę, os[ie]m ksiąg urodzeń obejmujących akty urodzeń od r. 1905 i jedną księgę zmarłych wspólną dla wszystkich gmin parafii prowadzoną od r. 1915.

${ }^{38}$ Tuwalnię zrobiły ss. felicjanki w Przemyślu za 25000 mk (APR, Księga dochodów i rozchodów, 1922 r.).

${ }^{39}$ Za figurę Matki Bożej, Jezusa Zmartwychwstałego i Jezusa w grobie, dwie pary kanonów, 1 lawabo, 2 pary ampułek z tackami z transportem p. Klukowi z Przędzela zapłacono w 1921 roku 42677 mk (APR, Księga dochodów i rozchodów, 1921 r.).

${ }^{40}$ Zostały one zakupione w 1922 roku za 46000 mk. Namalował ją Jan Bukowczyk z Krakowa. Parafianin z Racławic o nazwisku Woźniak oprawił je za 80000 mk w ramy z drzewa sosnowego (APR, Księga dochodów i rozchodów, 1921 r.).

${ }^{41}$ Autorką obrazu była Maria Waldeck, żona Mieczysława Józefa Waldecka (1879-1945), który w 1917 roku nabył od Maksymiliana Franckiego zespół dworsko-pałacowy z folwarkiem w Racławicach (S. Gurba, Twórczość artystyczna Marii Waldeck - malarki z Królewskiej Wsi Pysznica, „Kronika Diecezji Sandomierskiej”, 107 (2014) nr 5-6, s. 391-396; B. Barć, Mieczysław Fusek, w: Przeszli przez tę ziemię czyniąc dobro, s. 96.

${ }^{42}$ Wśród ofiarodawców z parafii racławickiej Agnieszka Rękas złożyła na figurę Matki Bożej datek w wysokości 7500 mk (APR, Ksiegga dochodów i rozchodów, 1921 r.).

${ }^{43}$ Ks. Wojciech Sapecki złożył od siebie na ten cel 4200 mk (APR, Księga dochodów i rozchodów, 1921 r.). 


\section{Pisma i akta kościelne}

Nie ma. Zniszczone w r. 1914 w czasie pożaru.

II.

A. Kapitały

a/. w publicznych obligacjach fundacyjnych.

ad $1 /$. Nie ma.

Ad 2.b/. Nie ma.

[s. 6]

$\mathrm{B} /$.

Znaleziono dwie książeczki wkładkowe Gal[icyjskiej] Kasy Oszcz[ędnościowej] we Lwo[w]ie44 Nr 2214722150 na 24 kor. 12 hal., ponadto znaleziono książeczkę wkładkową Gal[icyjskiej] Kasy Oszcz[ędnościowej] we Lwowie Nr $208^{44}$ na 210 kor. opiewającą.

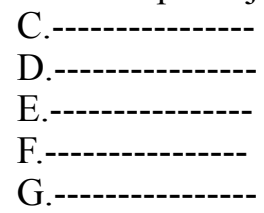

Znaleziono następujące książeczki wkładkowe Przemyskiej Kasy Oszcz[ędnościowej]:

$\mathrm{Nr} 43065$ fundacja mszalna śp. Jędrzeja Byry na kwotę 198 kor. 81 hal.

$\mathrm{Nr} 67929$ na 35 kor. 80 hal.

$\mathrm{Nr} 45323$ na 200 kor. jako fundacja mszalna Anieli Kostheim ${ }^{45}$

$\mathrm{Nr} 52276$ na 200 kor. jako fundacja mszalna Warchoły

$\mathrm{Nr} 25653$ na 21 kor. 08 hal. jako fundacja mszalna Kołodzieńskiego

$\mathrm{Nr} 49937$ na 197 kor. 84 hal. jako fundacja mszalna Kajetana Jamroza.

Nr 55055 na 200 kor. jako fundacja mszalna śp. Franciszka Dąbka.

$\mathrm{Nr} 58944$ na 200 kor. jako fundacja mszalna Agnieszki Kopeć

$\mathrm{Nr} 64288$ na 200 kor. jako fundacja mszalna Agnieszki Małek.

Ponadto znaleziono książeczki wkładkowe Przemyskiej Kasy Oczcz[ędnościowej $]^{46} \mathrm{Nr} 8927$ na 62 kor. i Nr 10057 na 226 kor. 82 hal. Przeznaczone na rzecz kościoła i probostwa w Racławicach. Wedle pisma Ordynariatu Biskupiego

${ }^{44}$ Galicyjska Kasa Oszczędności we Lwowie została założona w 1844 roku. Była to spółdzielnia oszczędnościowo-kredytowa (K. Broński, Rozwój gospodarczy większych miast galicyjskich w okresie autonomii, Kraków 2003, s. 35).

${ }^{45}$ Aniela Kostheim (+1901), żona Klemensa Kostheima (1840-1908), ziemianina, polityka, posła na Sejm Krajowy we Lwowie VII kadencji z okręgu Nisko, właściciela Zarzecza i Huty Deręgowskiej, (M. Kowalik, Klemens Kostheim (1840-1908), w: Przeszli przez tę ziemię czyniac dobro, s. 32-33).

${ }^{46}$ Kasa Oszczędności Miasta Przemyśla została utworzona w 1865 roku. 
obrz[ądku] rz[ymsko] kat[olickiego] w Przemyślu z dnia 17/2 1923 L: 932 wystosowanego do Urzędu Parafialnego w Racławicach znajdują się w przechowaniu Ordynariatu następujące książeczki Przemyskiej Kasy Oszcz[ędnościowej]: Nr 8319, 61763, 61766, 61871, 65258, 66795 i 69099. Następnie znaleziono listy zastawne Gal[icyjskiego] Tow[arzystwa] Kred[ytowego] ${ }^{47}$ ziemskiego $\mathrm{Nr} 636$ na 1000 kor., Nr 647 na 200 kor., Nr 1010 na 2000 kor. i Nr 1011 na 2000 kor. Prócz tego znaleziono obligacje Gal[icyjskiego] Fund[uszu] indemnizacyjnego $\mathrm{Nr} 1186$ na 200 kor. zawinkulowaną na rzecz fundacji mszalnej K[o]łodzieńskiego, $\mathrm{Nr} 348$ na 10000 kor., Nr 1275 na 2000 kor. Nr 244 na 1000 kor. Nr 1455 na 200 kor., $\mathrm{Nr}$ 2607 na 100 kor. winkulowane na rzecz probostwa w Racławicach.

\section{III.}

\section{Wydatki kościelne}

ad 1. Nie wydatkuje się.

ad 2. Pokrywa się z dobrowolnych składek zbieranych w niedzielę.

ad 3.

[s. 7]

\section{A. Opis plebanii i budynków gospodarczych}

ad. 1. Plebania została zniszczona w r. 1914 została jednak zrestaurowana w roku 1922.

ad. 2. Kuchnia i mieszkanie służby zostały zburzone w r. 1908.

ad. 4, 6. Dawna stajnia została spalona w r. 1914 wskutek strzałów armatnich a na jej miejsce postawiona w r. 1918 nowa stajnia na tej samej podmurówce z drzewa obejmująca osobne pomieszczenie dla bydła, osobne dla koni i osobne dla świń, stajnia ta kryta jest dachówką.

ad 5. Dawnego ustępu nie ma a na jego miejsce postawiono w r. 1918 nowy $\mathrm{z}$ desek.

ad 7. Spichlerz został spalony w r. 1914 wskutek strzałów armatnich. Spichlerz ten na miejsce dawnego został wystawiony w r. 1893.

ad 8. Stodoła drewniana wybudowana w r. 1893 spaliła się w r. 1914, na jej miejsce postawione zostały dwie szopy z desek pod jednym dachem o jednym boisku przykryte dachówką.

ad 9. Dawna studnia wybudowana w r. 1908 na miejsce drewnianej jest w stanie zniszczonym wskutek działań wojennych. Zbudowana jest $\mathrm{z}$ betonu.

ad 10. Oparkanienie deskowe kościoła na kamiennych słupach zostało zupełnie zniszczone w r. 1914 a na jego miejsce zbudowano nowy parkan sztachetowy na słupach drewnianych. Taki sam parkan okala z jednej strony od gościńca plebanię wraz z ogrodem ${ }^{48}$.

${ }^{47}$ Galicyjskie Towarzystwo Kredytowe Ziemskie zostało utworzone w 1842 roku (J. Hensel, Towarzystwa Kredytowe Ziemskie, w: Encyklopedia historii gospodarczej Polski do 1945 roku, t. 2, red. M. Kamler, Warszawa 1981, s. 410).

${ }^{48} \mathrm{Na}$ obrobienie słupów, żerdzi i opalenie słupów wydano 10700 , na ich ustawienie zaś wydatkowano 7000 mk (APR, Księga dochodów i rozchodów, 1921 r.). 


\section{B. Mieszkanie wikarego}

Mieszkanie wikarego znajduje się w budynku plebańskim.

\section{C.Organistówka}

Organistówka wybudowana w r. 1890 z drzewa kantowego szalowana deskami kryta dachówką zniszczona wypadkami wojennymi ${ }^{49}$. Obok znajdują się pod jednym dachem stajnia i stodoła na której nie ma dachu, gdyż został zniszczony w r. 1914.

\section{Trupiarnia}

Na cmentarzu znajduje się murowana trupiarnia wybudowana w r. 1908 kryta dachówką w stanie zniszczonym wskutek wypadków wojennych.

[s. 8]

\section{E. Cmentarz}

Oparkanienie cmentarza wykonane w r. 1913 zostało zniszczone w r. 1914 wskutek wypadków wojennych tak iż pozostały tylko zrujnowane słupy betonowe rygle zaś i sztachety spaliło wojsko ${ }^{50}$.

\section{V.FUNDUS INSTRUCTUS}

B. ad 5 i 10 bez skazy.

D.

ad 19. Jeden wałach i jedna klacz, siwe 5-io letnie.

ad 20. Wołów nie znaleziono natomiast zastano dwie jałówki które poprzednicy śp. Wojciecha Sapeckiego w drodze zamiany przyjęli za woły: jedna 3 letnia czarna krasa, druga 2 letnia czerwono krasa.

ad 21. Bez zmiany.

E.

Wedle zeznań członków Komitetu kościelnego w jesieni r. 1922 wysiano 480 $\mathrm{kg}$ żyta i $120 \mathrm{~kg}$ pszenicy.

ad $24,25,26,27$ i 28 bez zmiany.

ad 29 Nie znaleziono wedle zeznań członków Komitetu konopie nie były wysiewane.

${ }^{49}$ Długoletnim organistą w Racławicach był Karol Mróz (1902-1977). Po skończeniu szkoły dla organistów w Przemyślu w 1921 roku pracował nieprzerwanie do śmierci (B. Barć, Karol Mróz, w: Przeszli przez tę ziemię czyniąc dobro, s. 89).

${ }^{50}$ Cmentarz umiejscowiony na południowo-wschodnim krańcu Racławic założony w początku XIX wieku na planie kwadratu (Zabytkowe cmentarze i mogity w Polsce. Województwo tarnobrzeskie, oprac. M. Florek, Warszawa 1995, s. 122-123). 
VI.

A. ---------

B. Członkowie Komitetu zeznają:

Śp. Ks. Wojciech Sapecki obsiał w jesieni 19219 morgów żyta i 5 morgów przenicy [sic!], zaś na wiosnę 19225 morgów jęczmienia, 10 morgów owsa oraz obsadził 5 morgów kartofli. Z tego zebrał 36 kóp żyta, 15 kóp przenicy, 20 kóp jęczmienia, 40 kóp owsa i 25 cetn. metr. ziemniaków.

W r. 1920 ks. Sapecki sprzedał w porozumieniu z Komitetem kościelnym 2 1⁄2 morgi na cele odbudowy plebanii zaś w r. $1922 \mathrm{w}$ porze wiosennej sprzedał dalsze $2 \frac{1}{2}$ morgi na opłacenie daniny państwowej. Resztę gruntu wydzierżawił Ks. nieboszczyk przeważnie po 1 mordze drobnym dzierżawcom, którzy płacili 6000 marek czynszu rocznego od morga.

Prosa obsiał $1 / 2$ morgi z czego zebrał 3 kopy.

[s. 9]

Siek Franciszek mp.

Franciszek Karaś mp.

Jerzy Pieróg mp. Wojciech Młynarski mp.

Wojciech Dąbek zaprzysiężony taksator gminy po upomnieniu do sumiennego oszacowania zbiorów podaje następujące ceny:

$1 \mathrm{~m}$. żyta $16000 \mathrm{Mk} .1 \mathrm{~m}$. przenicy $20000 \mathrm{Mk}$. $1 \mathrm{~m}$. jęczmienia $8000 \mathrm{Mk}$.

$1 \mathrm{~m}$. owsa $8000 \mathrm{Mk} .1 \mathrm{~m}$. ziemniaków $4000 \mathrm{Mk}$. $1 \mathrm{~m}$. prosa $10000 \mathrm{Mk}$.

Koszt obsiewu żyta wysianego w jesieni zeszłego roku na 4 morgach szacuję na $140000 \mathrm{Mk}$. zaś koszt obsiewu przenicy wysianej na 1 mordze szacuję na $39000 \mathrm{Mk}$.

Do tych kosztów obsiewu wliczyłem naturalnie wartość wysianego zboża.

Antoni Łasica pełnomocnik masy spadkowej oświadcza:

Wojciech Dąbek mp.

Imieniem masy spadkowej zastrzegam jej prawa do majątku spadkowego pozostałego po śp. Wojciechu Sapeckim.

Ks. Gerard Kielar nowo instytuowany proboszcz oświadcza:

Antoni Łasica mp.

Majątek kościelny i beneficjalny przyjmuję i nie podnoszę żadnych zarzutów.

Na tym protokół zakończono i podpisano.

Ks. Gerard Kielar mp.

Ks. Michał Dukiet mp.

dziekan

Kornecki mp. urz. VII st. służ. 


\section{BIBLIOGRAFIA}

\section{Źródla}

Archiwum Archidiecezji Przemyskiej (AAP)

Akta personalne księży (Apk), Tabele służbowe (Ts).

Teczka z ankietami z 1945 r. o stanie parafii w czasie II wojny światowej, Teczka „K - Z”, Dekanat rudnicki, Ankieta parafii Racławice.

Archiwum Parafii Racławice (APR)

Dokumenty luźne.

Księga dochodów i rozchodów kasy kościelnej w parafii Racławice z lat 1919-1950.

Archiwum Kurii Metropolitalnej w Krakowie (AKMK)

sygn. AV-51, Acta visitationis ecclesiarum in archidiaconatu Sandomieriensi consistentium de speciali mandato Cel. Principis R.D. Cajetani Ignatii Sołtyk, episcopi Cracoviensis, ducis Severiae, per me Joannem Cantium Ligęza STD, ecclesiarum Insignis Collegiatae Sandomieriensis archidiaconum in Trójca curatum expeditae a.D. 1764 inchoatae annisque sequentibus 1765 et 1766 terminatae. (Decanatus: Połanecensis, Miechocinensis, Rudnicensis et Coprivnicensis).

sygn. AV-42, Acta visitationis in decanatibus Rudnicensi et Miechocinensi sub auspiciis et regimine Cel. R.D. Andreae Stanislai Kostka comitis in Załuskie Załuski, episcopi Cracoviensis, ducis Severiae, per me Andream Potocki canonicum ecclesiarum cathedralium Chelmensem et coadiutorem Cracoviensem archidiaconum et officialem Sandomieriensem, expeditae diebus Januarii, Februarii et Martii a. D. 1748.

Archiwum Szkoły w Racławicach

Kronika szkoły powszechnej w Racławicach.

\section{Opracowania}

Barć Bronisława (red.), Karol Mróz, w: Przeszli przez tę ziemię czyniąc dobro. Cmentarz w Racławicach, Stalowa Wola 2012. s. 89.

Barć B. (red.), Mieczysław Fusek, w: Przeszli przez tę ziemię czyniąc dobro. Cmentarz w Ractawicach, Stalowa Wola 2012, s. 96.

Broński Krzysztof, Rozwój gospodarczy większych miast galicyjskich w okresie autonomii, Kraków 2003.

Gurba Stanisław, Twórczość artystyczna Marii Waldeck-malarki z Królewskiej Wsi Pysznica, „Kronika Diecezji Sandomierskiej”, 107 (2014) nr 5-6, s. 391-396.

Hensel Joanna, Towarzystwa Kredytowe Ziemskie, w: Encyklopedia historii gospodarczej Polski do 1945 roku, t. 2, red. M. Kamler, Warszawa 1981, s. 410.

Janakowski Marcin, Inwentarz kościoła parafialnego w Chlewiskach z lat 1865-1866, „Z Dziejów Regionu i miasta: rocznik Oddziału Polskiego Towarzystwa Historycznego w Skarżysku-Kamiennej”, 6 (2015) s. 119-151.

Karkocha Małgorzata, Opis probostwa w Małogoszczu z 1856 roku, „Przegląd Nauk Historycznych", 17 (2018) nr 1, s. 143-170.

Kowalik Mariusz, Szczurowski Łukasz, Wojciech Sapecki, w: Przeszli przez tę ziemie czyniac dobro. Cmentarz w Racławicach, red. B. Barć, Stalowa Wola 2012, s. 53.

Kowalik Mariusz, Klemens Kostheim (1840-1908), w: Przeszli przez te ziemię. Przeszli przez tę ziemię czyniac dobro. Cmentarz w Racławicach, red. B. Barć, Stalowa Wola 2012, s. 32-33.

Kowalski Waldemar, Uposażenie parafii archidiakonatu sandomierskiego $w$ XV-XVIII wieku, Kielce 1998. 
Kracik Jan, Konsekracje kościołów i ołtarzy w diecezji krakowskiej w XVII-XVIII w., „Nasza Przeszłość", 61 (1984) s. 111-147.

Kufel Robert Romuald, Kancelaria, registratura i archiwum parafialne na ziemiach polskich od XII do poczatku XXI wieku, Zielona Góra 2011.

Kumor Bolesław, Dzieje diecezji krakowskiej do r. 1795, t. 4, Kraków 2002.

Kumor Bolesław, Granice metropolii i diecezji polskich (966-1939), „Archiwa Biblioteki i Muzea Kościelne", 19 (1969) s. 271-357.

Kumor Bolesław, Ustrój i organizacja Kościoła polskiego w okresie niewoli narodowej 1772-1918, Kraków 1980.

Markowska Elżbieta, Archiwum parafialne i jego zasób na przykładzie archiwum rzymskokatolickiej parafii pod wezwaniem Świętej Anny w Biatej Podlaskiej, „Radzyński Rocznik Humanistyczny", 7 (2009) s. 9-32.

Momidłowski Stefan, Wspomnienia pośmiertne o przemyskich kapłanach, Przemyśl 2019.

Moskal Tomasz, Duszpasterze parafii Racławice w latach 1918-1939, „Archiwa Biblioteki i Muzea Kościelne”, 92 (2009) s. 165-176.

Rawski Józef., Wybrane zagadnienia dotyczace administracji kościelnej $w$ widłach Wisty $i$ Sanu, Tarnobrzeg 1997.

Rocznik Diecezji Sandomierskiej 1994, red. Z. Kończak, Sandomierz 1994.

Szkutnik Piotr, Opis kościoła i probostwa w Szadku w połowie XIX w., „Biuletyn Szadkowski”, 15 (2015) s. 69-87.

Wizytacja kanoniczna dekanatu rudnickiego, dokonana przez ks. bpa sufragana Karola Józefa Fischera r. 1901, „Kronika Diecezji Przemyskiej”, 2 (1902) s. 366.

Wizytacja kanoniczna dekanatu rudnickiego, dokonana przez ks. bpa Józefa Sebastiana Pelczara wr. 1911, „Kronika Diecezji Przemyskiej”, 12 (1912) s. 516-517.

Wykaz kościołów diecezji przemyskiej ob. łać. wskutek wojny catkowicie zniszczonych lub częściowo uszkodzonych, „Kronika Diecezji Przemyskiej”, 17 (1917) s. 43-51.

Zabytkowe cmentarze i mogity w Polsce. Województwo tarnobrzeskie, oprac. M. Florek, Warszawa 1995.

Żurek Waldemar, Inwentarz rzymskokatolickiego kościoła parafialnego w Kobryniu z 21 sierpnia 1933 roku, „Archiwa Biblioteki i Muzea Kościelne”, 109 (2018) s. 399-412.

Żurek Waldemar, Inwentarz rzymskokatolickiego kościoła parafialnego $w$ Siehniewiczach z 14 maja 1930 roku, „Archiwa Biblioteki i Muzea Kościelne”, 110 (2018) s. 465-476.

Żurek Waldemar, Parafialny kościót farny świętych Joachima i Anny we Włodzimierzu Wotyńskim w 1831 roku, „Archiwa Biblioteki i Muzea Kościelne”, 111 (2019) s. 423-433.

\section{RACLAWICE PARISH INVENTORY OF 1923}

\section{Summary}

The parish of Racławice near Nisko was founded at the turn of the 13th and 14th centuries. Historical sources testify to the presence of at least 3 churches in the Old Polish period. In the middle of the 18th century, the owner of a part of Racławice and Przędzela, Józef Grabiński, founded the church, which burned down in 1914. After Poland regained independence in 1918, a new centre of worship was built. The temple was consecrated on May 8, 1922. The parish inventory of 1923 shows the effort made by the clergy and the faithful to equip the church with the necessary liturgical parameters.

Keywords: Racławice; parish church inventories; history of the Church 